\title{
EHMTI-0029. Medicated headache mask
}

\author{
M Hyson \\ From 4th European Headache and Migraine Trust International Congress: EHMTIC 2014 \\ Copenhagen, Denmark. 18-21 September 2014
}

\section{Introduction}

A topical treatment for migraine and/or tension headaches.

\section{Aims}

This study was performed to determine the efficacy of an anticephalgic photoprotective mask in conjunction with a topical medication containing bryonia and rhus toxicodendron in the treatment of migraine and/or tension headache.

\section{Methods}

Thirty-three patients were given masks and tubes of topical medication containing the bryonia and rhus toxicodendron. They were instructed to apply the medication to their frontalis and/or temporalis regions in the event they should suffer a headache and apply a photoprotective mask. Furthermore, they were instructed to take their usual oral or parenteral medications if required for the relief of the headache. They subsequently filled out forms rating the degree of relief which they attributed to the topical medication and the mask using a 0-10 scale. At the interview following the completion of their participation in the study, the patients were also simply asked if this form of treatment helped or not.

\section{Results}

Thirty out of 33 patients stated the medication and the mask were effective over and above the normal degree of relief they were receiving from their oral and/or parenteral medications. This study demonstrated a significant efficacy rate $(91 \%)$ in the treatment of migraine and/or tension headache with the anticephalgic mask in conjunction with a topical cream containing bryonia and rhus toxicodendron.

Neurology, University of Nevada, Las Vegas, USA

\section{Conclusions}

This study demonstrated a significant efficacy rate in the treatment of migraine and/or tension headache with the anticephalgic mask in conjunction with a topical cream containing bryonia and rhus toxicodendron.

No conflict of interest.

Published: 18 September 2014

doi:10.1186/1129-2377-15-S1-G15

Cite this article as: Hyson: EHMTI-0029. Medicated headache mask. The

Journal of Headache and Pain 2014 15(Suppl 1):G15.

\section{SpringerOpen $^{\circ}$}

C 2014 Hyson; licensee Springer. This is an Open Access article distributed under the terms of the Creative Commons Attribution License (http://creativecommons.org/licenses/by/2.0), which permits unrestricted use, distribution, and reproduction in any medium, provided the original work is properly cited.
Submit your manuscript to a SpringerOpen ${ }^{\circ}$ journal and benefit from:

- Convenient online submission

- Rigorous peer review

- Immediate publication on acceptance

- Open access: articles freely available online

- High visibility within the field

- Retaining the copyright to your article

Submit your next manuscript at $>$ springeropen.com 